\title{
Effects of a Training Workshop on Taiwan Teachers' Remedial Instruction: Results from a Case Study
}

\author{
Wen-Chi $\mathrm{Hu}^{1, *}$ \\ ${ }^{1}$ Department of English, National Taichung University of Education, Taichung, Taiwan \\ *Correspondence: Department of English, National Taichung University of Education, \\ No.140, Minsheng Rd., West Dist., Taichung City 40306, Taiwan. Tel: 886-4-2218-1020. \\ E-mail:winniehu@gmail.com
}

Received: October 12, 2016 Accepted: November 8, 2016 Published: December 3, 2016

doi:10.5296/ije.v8i4.10142ＵRL: http://dx.doi.org/10.5296/ije.v8i4.10142

\begin{abstract}
The Ministry of Education (MOE) in Taiwan proclaimed to strengthen underachievers' self-esteem and academic performance, the first Teacher Training Workshop on Remedial Teaching (TTWRT) was designed to cultivate qualified remedial teachers for further education policy movement. This study aimed to investigate 58 qualified remedial instructors' perceptions on their professional growth and support requirements under the impact of the reforms. The aim of this study was to ascertain remedial teachers' perceptions of demands, training satisfaction, and professionalism. Four significant findings are that (1) teachers lack the confidence to teach and promote remediation adequately; (2) teachers face the miscommunication among students, parents, schools, and administrative staffs; (3) teachers lack of remedial teaching materials and methods; and (4) teachers hold positive attitudes towards the professional remediation workshop. The results of this study assess the chances of success for teacher professional development preparing remedial teachers to implement the reforms.
\end{abstract}

Keywords: Twelve-Year Compulsory Education Program, Teacher Leaders, Remedial Instruction, Professional Development 


\section{Introduction}

Twelve-Year Compulsory Education Program was implemented in Taiwan in 2014. Based on the program's policy, The Ministry of Education (MOE) and K-12 Education Administration (K12EA) announced to ensure all underachieving students to receive supplemental education in 2013. MOE expects all students to succeed academically, and underachieving students who are the bottom third can be improved using appropriate series of instruction and assistance. To raise student confidence and academic performance, these students need more guidance and support than they are receiving to reach their potential. Learners' underachievement can be reversed as a result of modifications on both of the students and the teachers (Emerick, 1992). Therefore, the first Teacher Training Workshop on Remedial Teaching (TTWRT) was hosted by the Department of Elementary Education and the Education Research and Evaluation Center (CERE) at the National Taiwan Normal University (NTNU) in 2011. The purpose of the TTWRT was to cultivate qualified remedial instructors for further education policy movement. The importance of this study needed to be considered due to little understanding about remedial teachers in Taiwan. Furthermore, these qualified instructors in the future, were proposed to become teacher trainers in order to recruit and train more remedial teachers all around Taiwan. Since too few teachers are willing to commit to remedial instruction, it is difficult to narrow the achievement gaps between high-achievers and low-achievers. This study aimed to investigate these remedial instructors' perceptions on their professional growth and support requirements.

\subsection{Professional Development}

To enhance teacher competence, participating in professional development appeared to be the most popular method. Huang (2010) pointed out that "It is critical that professional development enables teachers to examine their teaching practices and personal theories, and to profit from working with others"(p.2). Additionally, Cooper (2008) suggested that effective professional development must include the four critical components: (1) presentation of theory, (2) demonstration of the strategy or skill, (3) initial practice in the workshop, and (4) prompt feedback about their teaching. Consequently, effective teacher professional development enriched the strategies, knowledge, aptitudes, and nature for learning that occurs within the education setting. After years of discussion and revision, the first TTWRT committee includes members from MOE, K12EA, and NTNU, they carefully designed the workshop to provide diversified ways to further enhance Taiwan teachers' knowledge and develop new instructional practices on remediation.

\subsection{Remedial Instruction}

In Taiwan, remedial instruction is one of the critical indicators for the measurement of contemporary educational reform. Also, scholars across content areas examined and proved the effectiveness of remedial program for a long period of time (Chang, 2001; Chan \& Li, 2002; Besty, 2002; Chen, 2004; Kams, 2005; Chen, 2007). Mandel \& Marcus (1995) argued that "underachievers are, in fact, highly motivated-in directions other than getting good grades. And finding out precisely where their motivation lies is the key to helping them turn around and become achievers at school” (p. 3). The supplementary program was important 
because it offered the possibilities for students who have low motivation, a lack of confidence, and low sense of success to actually experience learning achievement. Accordingly, underachievers made good progress through appropriate remediation. The concept of remedial instruction was to strengthen learners' weaknesses and low-achieving performance (Nederveld, 1967; Bereiter, 1985; Meyler, Keller, Cherkassky, Gabrield, \& Just, 2008; Wehmeyer, Shogren, Palmer, Williams-Diehm, Little, \& Boulton, 2012). Remediation mainly focused on individual learners to uplift their learning achievements. However, not every education stakeholder had the awareness of how to teach remediation. Identifying and motivating underachievers were essentials for quality education, but training qualified remedial teachers is the first step to accomplish the goal.

\section{Methods}

\subsection{Participants}

By using purposeful sampling, 58 qualified remedial instructors were invited to participate in this study. The participants of this study were expected to share their learning in remedial instruction with their local colleagues and to promote better remedial education. After taking The first TTWRT, all qualified teachers were encouraged to promote remediation by conducting remedial courses for underachievers or become teacher trainers to recruit and train more remedial teachers in Taiwan.

Table 1. Description of the Samples

\begin{tabular}{llrc}
\hline & & Numbers of respondents & Percentage \\
\hline Gender & Male & 16 & $27.59 \%$ \\
Living area & Female & 42 & $72.41 \%$ \\
& North of Taiwan & 33 & $56.90 \%$ \\
& Middle of Taiwan & 17 & $29.31 \%$ \\
Education levels & South of Taiwan & 8 & $13.79 \%$ \\
& Bachelor degree & 16 & $27.59 \%$ \\
& Master's degree & 36 & $62.07 \%$ \\
Conducting & Doctoral degree & 6 & $10.34 \%$ \\
remedial courses & Remedial course on & 41 & $70.69 \%$ \\
& progress & & \\
& No remedial course & 16 & $27.59 \%$ \\
& Remedial course will be & 1 & $1.72 \%$ \\
\hline
\end{tabular}

\subsection{Instruments}

The design of the study contained documents analysis, observation, field notes, end-of-session questionnaires, and interview questions to collect data. The case study allowed the opportunity to examine the remedial instruction training as a whole, giving an in-depth 
look at the experience from teachers' diverse perspectives (Merriam, 1998). The end-of-session questionnaires(as appendix) consisted questions of background information, workshop experience, and open-ended questions. These questions were used to explore teachers' views on the current policy, demands of professional training, and major problems in the field of remediation. Then, research questions were designed to explore remedial instructors' challenges while facing remedial policy promotion. The research questions for this study focused on teacher perceptions and implementation of the first Teacher Training Workshop on Remedial Teaching (TTWRT). More specifically: What are the gains and demands that teachers' views of essential elements for effective remedial instruction for low-achievers and all stakeholders in Taiwan? This study had the attempt to apply an inquiry approach to learn remedial teachers' professional needs and perspectives depending on their remedial workshop experience.

\subsection{Data Analysis}

Data collected through the questionnaires were keyed in to the Microsoft Word document. Total responses from the Likert scale were separated and percentages calculated. Open-ended data were divided into chunks and themes that labeling with different color codes. General notes were written to develop rich descriptive stories about these participants (Merriam, 1998; Creswell, 2003). Member checking and triangulation were used in order to ensure validity of the study. After the first draft of the descriptive data was conducted, the researchers arranged focus group meetings in different school districts across Taiwan. Qualified remediation teachers were invited to review, discuss, and share the data findings with the researchers.

This qualitative empirical study comprised of literature and documents relates to the first TTWRT. The documents include official workshop registrations from the K12EA, MOE education policies, and official Twelve-Year Compulsory Education Program. Also, using end-of-session questionnaires, semi-structured interview, and focus group discussion to collect data from teachers who attended the TTWRT. After the workshop, end-of-session questionnaires were used to collect immediate feedbacks from participants. From the results, three major concerns were found as table 2:

Table 2. Remedial Teachers’ Major Concerns

\begin{tabular}{ll}
\hline Concerns & Issues relates to remedial instruction \\
\hline Instructional & 1. Lack of adequate remedial teaching materials and strategies \\
issues & 2. No support team for classroom teaching challenges \\
& 3. Lack of desire and confidence to teach remedial classes \\
Administration & 1. Miscommunication between students, parents and school staffs \\
& 2. No standardized regulations and resources from local governments and schools \\
Workshop & 3. No clear laws and policies to follow \\
feedbacks & 1. Teachers show positive feedbacks about the efficiency of the workshop \\
& 2. Expect more advanced training for classroom management, assessment, and \\
& 3. counseling...etc.
\end{tabular}


Expanded from the three remedial teacher's concerns, further interviewing questions were designed to better discover participants' attitudes, thoughts, and demands about promoting remedial education to their local districts. The interviewing questions were: (1) What are your feedbacks from the first Teacher Training Workshop on Remedial Teaching (TTWRT)? (2) How would you apply your knowledge from the workshop to promote future remedial instruction? (3)What are your experiences with teaching remedial courses at your school? (4) What are the materials that you will use in teaching remedial courses? (5) What do you think are the best strategies that you have learned to facilitate the students in remedial courses? (6)What were the challenges that you have encountered in teaching remedial courses? All transcriptions were read and coded into meaningful categories for further analysis (Glaser, 1992). Qualitative interviewing can be regarded as data gathering device which is more effective to retrieve participants' stories and thoughts (Ely, Anzul, Friedman, Garner, and Sterinmetz, 1991). Furthermore, workshop observations were conducted to further witness the actual setting, especially how the teachers gained the knowledge and how the workshop would facilitate their remedial teaching. Video and audio recordings were used during the interview, focus group discussion, and workshop observation.

\section{Findings}

The findings were the answers to the research questions on teacher perceptions and implementation of the first (TTWRT). Four major findings helped to clarify the practical experiences of remedial instructors' concerns and difficulties. These results fostered policy makers and all stakeholders to get involved with effective remedial program and policies as well as to recognize teachers' problems and needs. The main findings of this study were: (1) teachers lack the confidence to teach and promote remediation adequately; (2) teachers face the miscommunication among students, parents, schools, and administrative staffs; (3) teachers lack remedial teaching materials and methods; and (4) teachers hold positive attitudes towards the professional remediation workshop. Future suggestions based on the results and findings are provided in the study.

\subsection{Teachers Lack the Confidence to Teach and Promote Remediation Adequately}

\subsubsection{Teacher Overload}

The findings indicated that teachers found the first TTWRT effective and relevant. However, many of them were overwhelmed by work loading, lack of time, and information overload. For instance, teachers felt frustrated with the overwhelming amount of new knowledge and teaching methods that emanated from the training workshops. One teacher exclaimed, "there are so much information that I have to learn from the training and I do not have time to do so...I have other works to do". While the professional training is relevant, participants felt frustrated about the difficulties of applying all new ideas and knowledge taught through the professional development. One teacher expressed, "they give us all that information and what am I going to do with it?” A teacher said, "I feel frustrated and worried, how can I use the materials for my own remedial class and also ‘teach' other teachers? I think I need more time 
to prepare”. Admittedly, non-teaching duties such as MOE's Advisory Group duties and supervisor duties consumed the teachers' time and energy. One teacher said, "I don't have the control of the time because I am already the member of Advisory Group for the K12EA". The complaints associated with time issues are the major challenge for teachers across all grade levels. Moreover, many of the participants said that they are not ready to take the responsibilities for remedial instruction at their local schools. Even though many teachers have a fruitful experience while attending and receiving professional development, they still question that implantation is impossible due to their low-confidence on remediation.

\subsubsection{Teacher Efficacy}

The reason for conducting the first TTWRT is because the quality of the remedial teacher workforce is of considerable concern to Taiwan education policymakers. Students' learning achievement and academic success depend in no small part on the efficiency of teachers. Due to the newly released Twelve-Year Compulsory Education Program, there has been a strong policy push toward getting more qualified teachers into the remedial instruction. The main problem for remedial teacher efficacy is that there is no enough individuals to teach and many of them are inexperienced. According to one participant, "there are a lot of teachers that obviously know well in their content areas...like math, English... or science, but not every teacher knows how to teach remediation”. Hence, generating more alternative pathways to recruit and train remedial teachers have sought to bring more academically accomplished individuals to collaborate with the government. Another teacher claimed, "to be honest with you, as an experienced teacher myself, I do not know remedial education well enough to effectively teach it or even promote it to more teachers". Thus, the study results found that more practice-oriented workshops should be provided because this might allow inexperienced remedial teachers to learn methods and strategies in an effective manner.

\subsection{Teachers Face the Miscommunication among Students, Parents, and Schools}

The critical beneficial aspect of teaching is having positive relationships with students, parents, and the school. Effective partnership with students and parents is vital for a teacher to be successful. However, participants in the study felt that all the stakeholders including students, parents, and school district administrators did not understand the remedial education and Twelve-Year Compulsory Education Program. Remedial teaching is to rearrange academic underachieving students to receive more inclusive instruction where they are integrated with typically developing peers. A teacher recounted, "parents do not want their kids to be labeled as disadvantaged learners or underachieving students, therefore they do not like the idea of remedial teaching". One participant said, "students will tease those who attend remedial courses because they think remediation is for stupid". If the government add students and parents to the remedial workshops, then they might understand better about remedial program which is meant to facilitate underachievers' learning motivation and academic achievements. Remedial teachers need their encouragement and support. One teacher commented, "I hope (that) if the MOE help more parents to know remediation is not a punishment for their children, but for their own good, we are trying to help them learn in a more realistic way". 
Likewise, many teachers felt that their efforts at remediation workshop are not supported by their administrators. School administrators often failed to recognize teachers' efforts on a variety of non-instructional duties: such as attending staff meetings, being supervisors, parent conferencing, curriculum planning, and professional responsibilities (Olson \& Chalmers, 1997). While teachers are overloaded and lack of understanding from the community, they felt challenged to promote remedial education to students, parents, and administrators. It is challenged to promote remedial teaching for entire school by involvement of new policies and information. They required more support and collaboration to process and implement the information from the professional development training workshops. One teacher stated, "the training sessions offered too much (and) too fast information...parents...even other teachers may not understand it". A participant said, "I think parents and school members should be invited to the workshop" and "they (parents and students) deserve to know the reasons why we are having remedial education". Another added, "they (school staffs) all need to come to take the courses (remediation professional development)...then they will work with us". Teachers said that they had insufficient support from administrators to fully implement professional development knowledge or to promote remedial instruction policies. For instance, one teacher stated, "it can be difficult to plan for so much in so short a time scale without school staffs' help”. Another teacher pointed out, “seems like (after the workshop) I become the only expert knows about remedial program, and no one in my school knows about it... they are not willing to know and participate in it”.

Teachers suggested the government should also set up standardized policies and rules for all stakeholders to follow. Remedial teachers must not only prove their capacity for dealing with students but must also convey to their colleagues. Thus, a successful remedial instructor should be able to gain the cooperation and support of teachers, administrators, students, and parents.

\subsection{Teachers Lack Remedial Teaching Materials and Methods}

After the first TTWRT, teachers believe they have insufficient strategies, materials, and resources to promote remediation. Obviously, the methodology that remedial teachers use will be essentially different from that of mainstream classroom. Effective remedial teachers, therefore, must be familiar to adapt a variety of teaching activities and methods to help students develop their potential and eliminate the obstacles in learning. One participant argued, "we only attended a few workshops and how can we remember all these strategies and use them?" A teacher said, "I am not sure if I have enough teaching materials or lesson plans now to promote remediation". Another teacher asked, "how can I help students recognize and learn to function effectively in a variety of activities when I am not familiar with all the remedial materials?” In addition to this, many remedial students have continually experienced failure by conventional classroom methods, they deserve better and different teaching strategies. Unfortunately, a teacher stated, "usually we just teach them same content repeatedly and that's what we think about remediation". A teacher commented, "in our school we have insufficient material resources and staff, and teachers are either untrained or unwilling to be trained about remediation". Teachers expect the MOE to provide them with supplementary teaching materials. Also, many participants suggested to have an exchanging 
system for lesson plans and teaching resources across content-areas. Another teacher said, "when we feel powerless, at least we may find some help from other teachers from other districts in the system". One teacher added, "it can be like an online discussion forum or web site for remedial teachers to share and ask questions”. Teachers stated that they need appropriate learning activities but they lack of time to design on their own. Thus, the government serves a critical function to design and offer standardized instructional references or manuals for teachers.

\subsection{Teachers Hold Positive Attitudes towards the Professional Remediation Workshop}

According to remedial teachers' feedbacks after the first TTWRT, they consider professional development is relevant to the students' needs. Many of the participants said there is value in continuing to pursue teacher training which provides a vehicle for teachers to enrich their instruction. One teacher stated, "as a teacher, of course I want to know more ways to make my students successful... and that's why I am here”. Many teachers acknowledged the efforts to link professional development to facilitating remedial learners' achievement. One teacher stated, "...the most important thing I learned from the workshop is that all learners can learn...it just depends on what guidance teachers offer to them”. Teachers believed that professional development training help them to know these underachieving students better. One of the teachers recounted, "remedial workshop provides great opportunities for us to collaborate with other teachers, to observe students' learning difficulties, and to be familiar with how to be a 'coach' rather than a lecture in the classroom”. Students underachieve due to diverse reasons, therefore, the challenge for remedial teachers is to discover the individual key to motivate learners' interests and attitudes. A teacher remarked, "I find one important thing from the training: one-size does not fit all, especially in teaching”.

Furthermore, teachers believed that the professional development from TTWRT seems to be necessary for all teachers to be better prepared for the newly released Twelve-Year Compulsory Education Program. According to one participant, "before this workshop I do not really know why we need to do remediation, now I get it". Also, one teacher mentioned, "(the workshop) open my eyes, and I wonder what else we could use to teach in different curricular areas”. Many of the participants stated that the amount of remedial materials was sufficient. One said, "I think I really gain something from the workshop...but... maybe the workshop could offer more activities and courses like classroom management or low-achievers' motivation...something like that". Additionally, one teacher said, "I will use everything that I learn from the workshop...like remedial teaching techniques, remedial education psychology, collaborative learning, and in-class activities, they are useful to me”. Moreover, teachers are glad to see the TTWRT recorded and included all their suggestions and recommendations for future workshop planning. One teacher said, "I appreciate the MOE and the workshop(TTWRT) because our concerns are valued and we think our efforts have been noticed by policymakers”. 


\section{Discussion}

Increasing numbers of educators are seeking professional learning to meet their professional development needs and apply that learning to increase student achievement. This case study examine the views of teachers from all around Taiwan about the attitudes of the new remediation policy and remedial knowledge for professional development. Findings indicate that the teachers felt it was an effective workshop. Thematic analysis implies that teachers felt it was important to interact with and learn from other educators who are located across different districts and content-areas. Furthermore, additional teaching resources and supports are critical in terms of promoting the new program policy among Taiwan. Indeed, the first TTWRT workshop creates professional development opportunity to teachers. The response to the workshop of reflective teachers includes positive professional growth, teacher burnout, and uncertainty for promoting new remediation courses to better fulfill underachievers' academic needs.

The findings of the study guide the effectiveness of the professional development workshops focusing on remediation policy, strategies, and knowledge. First, many teacher are hesitated to teach and promote remediation. This case study can foster educational change throughout Taiwan by improving the awareness of the new remediation policy, which will likely improve the academic environment for low-achievers. Moreover, teachers face the challenge to build trust with students, parents, schools, and administrative staffs. Thus, by improving the communication between all stakeholders, students are more likely to succeed academically. Third, many teachers lack the competence and methods which is necessary to handle mixed ability learners. The first TTWRT workshop emphasizes on remedial teaching and it fosters the collaborative efforts of the teachers and academics across content-areas and grade levels. Likewise, it improves the academic outcomes of the remedial courses in Taiwan school districts. Finally, teachers' attitudes towards the professional remediation workshop are positive. The TTWRT workshop promotes an environment where participants experience great ideas sharing, reflect on best practices, and interact with scholars and practitioners from diverse backgrounds. As this was the most common emergent theme, it is important to teachers to exchange information about using the resources in their classrooms, across diverse contexts.

\section{Conclusion}

Educational reform movements in Taiwan are setting ambitious goals for all learners. Notwithstanding, the changes in classroom practices demanded by the reform prospects ultimately depend upon teachers (Nederveld, 1967; Fullan \& Miles, 1992; Spillane, 1999; Chen, 2007). Teachers who carry the mission of promoting remediation will not succeed without efforts, support, and guidance. Therefore, the professional development for remedial teachers is essential to efforts to help underachieving learners. Throughout the study, teachers across content areas shared beliefs about professional development of TTWRT. When the MOE addresses the teachers' concerns for systematic professional training, diversified teaching approaches and resources, adequate support from stakeholders, and clear regulations 
in remediation, the issues of information overload, lack of teacher efficacy, and lack of confidence for teachers will be met. The first TTWRT provides the opportunities that will help Taiwan teachers enhance their knowledge, support, resources, and develop new instructional practices for remediation. The study findings suggest that continuous workshops and relevant education policy should be conducted/ in order to raise the level of awareness and cooperation among all education stakeholders for underachieving students' future achievements.

\section{Acknowledgement}

The author of the study thanks Professor Hsiao-Lan Chen and Professor Li-Yu Hung from the National Taiwan Normal University (NTNU) and the K-12 Education Administration (K12EA) for providing source data and project funding.

\section{References}

Bereiter, C. (1985). The changing face of educational disadvantagement. Phi Delta Kappan, 66(8), 538-541.

Best, J., \& Kahn, J. (1993). Educational research. Boston: Allyn and Bacon.

Betsy, O. (2002). Remediation at the community college: Pressing issues, uncertain solutions. New Directions for Community Colleges, 117, 35-44. http://dx.doi.org/10.1002/cc.51

Chan, Y.W., \& Li, C. S. (2001). Form-focused remedial instruction: An empirical study. International Journal of Applied Linguistics, 12(1), 24-53. http://dx.doi.org/10.1111/1473-4192.00023

Chang, S. Z. (2001). Effective Remedial Programs and Instruction. Education Journal, 17, 85-106.

Chen, K. T. (2007). Underachieving students' improvements in a primary EFL remedial program. MingDao Journal of General Education, 2, 263-277.

Chen, Y. H. (2004). Elementary and junior high school English teachers' perceptions and implementation of remedial instruction for underachievers. (Unpublished Master thesis). National Taiwan Normal University, Taipei, Taiwan.

Cooper, J. D. (2008). Professional development: An effective research-based model. Boston, MA: Houghton Mifflin Harcourt. Retrieved from http://www.washingtonstem.org/STEM/media/Media/Resources/Professional-DeveloPm ent-An-Effective-Research-Based-Model-COOPER.pdf.

Creswell, J. W. (2003). Research design: Qualitative, quantitative, and mixed methods approaches. London: Sage.

Ely, M., Anzul, M., Friedman, T., Garner, D., \& Sterinmetz, A. (1991). Doing qualitative research: Circles within circles. London: The Falmer Press.

Emerick, L. J. (1992). Academic underachievement among the gifted: Students’ perceptions 
of factors that reverse the pattern. Gifted Child Quarterly, 36, 140-146. http://dx.doi.org/10.1177/001698629203600304

Fullan, M. G., \& Miles, M. B. (1992). Getting reform right: What works and what doesn't. Phi Delta Kappan, 73, 745-752.

Glaser, B. G. (1992). Basics of grounded theory analysis. Mill Valley, CA: Sociology Press.

Huang, Y. C. (2010). Taiwanese teachers' beliefs about professional growth in shin-Ju District. International Journal of Education, 2(2), 1-29. http://dx.doi.org/10.5296/ije.v2i2.545

Kams, M. (2005). Inoculating against low achievement. Leadership, 34(3), 12-38.

Mandel, H. P., \& Marcus, S. I. (1995). “Could do better”: Why children underachieve and what to do about it. New York: John Wiley and Sons, Inc.

Merriam, Sharan B. (1998). Qualitative Research and Case Study Applications in Education. San Francisco: Jossey-Bass.

Meyler, A., Keller, T.A., Cherkassky, V.L., Gabrieli, J.D.D., \& Just, M.A.(2008). Modifying the brain activation of poor readers during sentence comprehension with extended remedial instruction: A longitudinal study of neuroplasticity. Neuropsychologia, 46, 2580-2592. http://dx.doi.org/ 10.1016/j.neuropsychologia.2008.03.012

Nederveld, M. (1967). The Effective Remedial Reading Program, Reading Horizons, 2(7), 75-80.

Olson, M. R., \& Chalmers, L. (1997). Attitudes and attributes of general education teachers identified as effective inclusionists. Remedial and Special Education, 8(1), 28-36. http://dx.doi.org/10.1177/074193259701800106

Spillane,J . P. (1999). External reform initiatives and teachers efforts to reconstruct practice: The mediating role of teachers' zones of enactment. Journal of Curriculum Studies, 3(1), 143-175. http://dx.doi.org/10.1080/002202799183205

Wehmeyer, M.L., Shogren, K., Palmer, S., Williams-Diehm, K., Little, T., \& Boulton, A. (2012). Impact of the Self-Determined Learning Model of Instruction on student self-determination. Exceptional Children, 78(2), 135-153.

\section{Appendix}

Appendix 1. Sample End-of Session Questionnaire

Part I.

District/School: Gender: $\square$ Male, $\square$ Female

Grade level: $\square$ Elementary, $\square$ Middle school, $\square$ High school, $\square$ College

Content-Area: $\square$ Math, $\square$ Science, $\square$ English, $\square$ Chinese, $\square$ History, $\square$ Other

Position Title/Role: Years of teaching : 
Education background: $\square$ Bachelor $\square$ Master's $\square$ Doctoral degree

Number of remediation courses that you are teaching currently: $\square$ None, $\square$ 1 2, $\square 3 \sim 4$,

$\square$ more than 5, $\square$ other

Part II.

\begin{tabular}{|c|c|c|c|c|c|}
\hline & $\begin{array}{l}\text { Strongly } \\
\text { Disagree }\end{array}$ & $\begin{array}{l}\text { Somewhat } \\
\text { Disagree }\end{array}$ & $\begin{array}{c}\text { Neither Agree } \\
\text { nor Disagree }\end{array}$ & $\begin{array}{c}\text { Somewhat } \\
\text { Agree }\end{array}$ & $\begin{array}{l}\text { Strongly } \\
\text { Agree }\end{array}$ \\
\hline $\begin{array}{l}\text { 1. The workshop courses are well } \\
\text { organized. }\end{array}$ & $\mathrm{C}$ & $\mathbb{C}$ & $\mathrm{C}$ & $\mathbb{E}$ & $\mathrm{C}$ \\
\hline $\begin{array}{l}\text { 2. Instructors in the workshop courses } \\
\text { are well prepared. }\end{array}$ & C & C & $\mathrm{C}$ & $\mathrm{C}$ & $\mathrm{C}$ \\
\hline $\begin{array}{l}\text { 3. The workshop courses are useful to } \\
\text { my remediation teaching. }\end{array}$ & C & $\mathrm{C}$ & $\mathrm{C}$ & $\mathbb{C}$ & C \\
\hline $\begin{array}{l}\text { 4. The workshop courses are } \\
\text { beneficial to my professional needs. }\end{array}$ & $\mathbb{C}$ & $\mathrm{C}$ & $\mathrm{C}$ & $\mathrm{C}$ & $\mathrm{C}$ \\
\hline $\begin{array}{l}\text { 5. Overall, I am satisfied with the } \\
\text { workshop. }\end{array}$ & $\mathrm{C}$ & $\mathrm{C}$ & $\mathrm{C}$ & 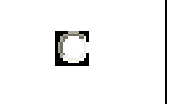 & $\mathrm{C}$ \\
\hline
\end{tabular}

Part III.

1. What was the most useful part of this workshop? Why?

2. What was the least useful part of this workshop? Why?

3. What additional training do you need?

4. What additional support do you need?

5. How will you use what you have learned?

6. Other comments:

\section{Copyright Disclaimer}

Copyright for this article is retained by the author(s), with first publication rights granted to the journal.

This is an open-access article distributed under the terms and conditions of the Creative Commons Attribution license (http://creativecommons.org/licenses/by/3.0/). 